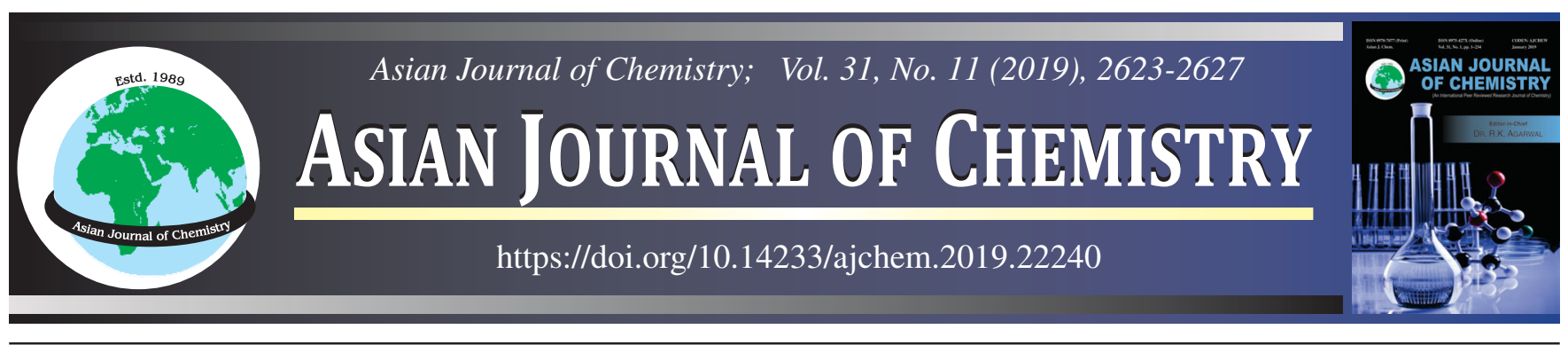

\title{
Cytotoxic and Antibacterial Activity of Selected Medicinal Plants used in South African Traditional Medicine
}

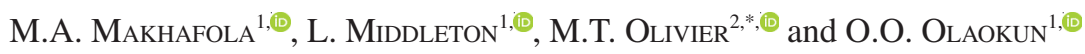

${ }^{1}$ Department of Biology, Sefako Makgatho Health Sciences University, P.O. Box 139, Medunsa, Pretoria 0204, South Africa

${ }^{2}$ Department of Chemistry, Sefako Makgatho Health Sciences University, P.O. Box 235, Medunsa, Pretoria 0204, South Africa

*Corresponding author: Tel: + 2712 5214370, E-mail: Olivier.mutendela@gmail.com

Received: 3 June 2019;

Accepted: 22 July 2019;

Published online: 28 September 2019;

AJC-19597

Five plants were investigated for their antibacterial and cytotoxicity activities, namely: Lantana rugosa, Lippia javanica, Lippia wilmsii, Hilliardiella elaeagnoides and Withania somnifera. Four organisms and liver cells were used to evaluate the efficacy and the safety of the extracts from these plants. All the extracts showed antibacterial activity with the MIC ranging from $0.04 \pm 0.04 \mathrm{mg} / \mathrm{mL}$ to $11.46 \pm 9.66$ $\mathrm{mg} / \mathrm{mL}$. The acetonic extract of $L$. javanica exhibited the highest antibacterial activity with MIC value of $0.04 \pm 0.04 \mathrm{mg} / \mathrm{mL}$ against $P$. aeruginosa and $0.28 \pm 0.35 \mathrm{mg} / \mathrm{mL}$ against $S$. aureus. Aqueous and acetonic extracts of $L$. wilmsii $\left(\mathrm{LC} \mathrm{C}_{50}>1000 \mu \mathrm{g} / \mathrm{mL}\right)$ and the hexane extract of $L$. javanica $\left(\mathrm{LC}_{50}>1000 \mu \mathrm{g} / \mathrm{mL}\right)$ were the least cytotoxic. While acetonic extract of $L$. javanica $(0.01 \pm 0.64 \mu \mathrm{g} / \mathrm{mL})$ and hexane extract of $L$. wilmsii $(0.03 \pm 0.31 \mu \mathrm{g} / \mathrm{mL})$ were the most cytotoxic.

Keywords: Antibacterial activity, Cytotoxicity, Lantana rugosa, Lippia javanica, Lippia wilmsii, Hilliardiella elaeagnoides, Withania somnifera. ᄂ 一 - - - - - - - - - - - - - - - - - - - - - - - - - - - - -

\section{INTRODUCTION}

Infectious diseases are a threat to the lives of many people worldwide [1]. Most infectious diseases in human beings are caused by bacterial agents such as Staphylococcus aureus, Escherichia coli, Pseudomonas aeruginosa, Bacillus subtilis, Proteus vulgaris [2] and many other microorganisms like fungi and viruses [3]. Phytochemicals also known as secondary plant metabolites in some plants possess antibacterial, antifungal, anti-inflammatory properties and other pharmacological activities. Such properties from plants have been recognised and used in the practice of traditional medicine to treat, heal and cure various diseases [4].

The plants under investigations are commonly used in South African traditional medicine as infusions, decoctions and tonics for treating diseases such as fever, colds, inflammation of the nasal passage, cancer and others. There is an assumption that these plants are effective and relatively safe for human consumption, because of their long history as curatives in traditional medicine. Despite the reputedly remedial benefits of such medicinal plants, a more rigorous evaluation may thus reveal the presence of toxic constituents harmful to the human body when ingested. These toxic compounds could impair the functions of various organs, such as the heart, liver, lungs, kidneys and brain.

Some examples of plant-related poisoning occasioned by taking a traditional medicinal remedy, could be ascribed not necessarily to the inherent toxicity of plant mixture but rather to the administering an incorrect dosage, misidentification of plant type or part, or otherwise adverse metabolic or systemic reaction in individual cases $[5,6]$. Cases of severe to fatal plantbased poisoning, linked to the intake of traditional medicinal preparations, have been reported in South Africa. According to Joubert [7], $17.5 \%$ of patients admitted to George Mukhari Hospital in Ga-Rankuwa, South Africa, between 1981 and 1985, were due to traditional medicinal poisoning, with a fatality rate of $15.2 \%$ [8]. A later study in 1996 by Osuch [9] showed that $9.2 \%$ of patients admitted to the same hospital from 1987 to 1992 were caused by the same form of poisoning, with a slightly lower fatality rate of $13.42 \%$. A relatively recent study by du Plooy et al. [10] in 2001 found that between 1996 and 2000 the number of patients admitted to the same hospital owing to traditional herbal medicine poisoning had decreased by an average of six to one case per year (4.7\% of all admissions and 5.10 $\%$ or total deaths). Even though recorded instances of this type

This is an open access journal, and articles are distributed under the terms of the Attribution 4.0 International (CC BY 4.0) License. This license lets others distribute, remix, tweak, and build upon your work, even commercially, as long as they credit the author for the original creation. You must give appropriate credit, provide a link to the license, and indicate if changes were made. 
of poisoning appear to be decreasing, that by no means mean that the tolerable levels of toxicity of all plants used in this way have been determined, while, at the same time, the use of plantbased traditional medicinal remedies remain widespread and popular.

The current study therefore targeted five commonly used plants to assess their antibacterial activity and cytotoxicity. The plants under investigation in this study are Lippia javanica, Lantana rugosa, Hilliardiella elaeagnoides, Withania somnifera and Lippia wilmsii as described in Table-1. The extracts of these plants were investigated for antibacterial activity against four bacterial agents as well as for cytotoxicity against C3A liver cell line.

\section{EXPERIMENTAL}

The plants Lantana rugosa (PRE0993728-0), Lippia javanica (PRE0993729-0), Lippia wilmsii (PRE0993726-0), Hilliardiella elaeagnoides (PRE0993727-0) and Withania somnifera (PRE0993725-0) were collected during the summer from their natural habitats at two locations in January 2016 at Sefako Makgatho Health Sciences University campus in Ga-Rankuwa Gauteng (-25.614500, 28.030082) and in February 2016 at Moteti village in Limpopo province $(25.230664,29.049750)$. After collection, the plants were taken to the laboratory where they were washed under running water to remove dirt then the leaves were separated from the stem and spread out to dry in a cool shady place. The dried leaves were grinded to fine powder in a blender. The powdered plant materials were then stored in paper envelopes until further usage.

The extraction was according to the method described by McGaw et al. [16] where by the powdered plant materials were separately extracted using each of the five different solvents, namely ethyl acetate, acetone, methanol, hexane and water. For water extracts, $3 \mathrm{~g}$ of each powdered leaf material were weighed into a beaker, then mixed with $30 \mathrm{~mL}$ of distilled water before being boiled in a water bath for $10 \mathrm{~min}$. Each boiled mixture was centrifuged at $1000 \mathrm{rpm}$ for $5 \mathrm{~min}$, filtered and the filtrate was air-dried at room temperature. The methanol, ethyl acetate, hexane and acetone extracts were obtained by adding $30 \mathrm{~mL}$ of solvent to $3 \mathrm{~g}$ of each powdered leaf material which was shaken for $30 \mathrm{~min}$ and centrifuged at $1000 \mathrm{rpm}$ for $5 \mathrm{~min}$. The filtrates were air-dried at room temperature under a stream of cold air. This extraction process was repeated three times in respect of each solvent.

General procedure: Four microorganisms were involved in this assay, namely two Gram-positive bacteria $S$. aureus (ATCC 29213) and E. faecalis (ATCC 29212) and two Gramnegative bacteria $E$. coli (ATCC 25922) and P. aeruginosa (ATCC 27853). The microplate method [17] was used to determine the minimal inhibitory concentration (MIC) values for plant extracts with antibacterial activity. Mueller Hinton broth (150 $\mu \mathrm{L}$ ) was pipetted into each well of the 96-wells plate. Thereafter, $75 \mu \mathrm{L}$ of extract solution (hexane, acetone, ethyl acetate, methanol or water) $(1 \mathrm{mg} / \mathrm{mL})$ was prepared in water and 0.5 $\mathrm{mL}$ acetone to allow the extracts to dissolve, because it does not completely dissolve in water alone. This was added to the first wells of the 96-well plates followed by a five-fold serial dilution. An overnight bacterial suspension $(35 \mu \mathrm{L})$ grown on New York City plate (GC-agar) was added to each well. Extractfree solution was used as a blank control while Gentamicin solution was used as positive control. The microtiter plates were sealed and anaerobically incubated for $24 \mathrm{~h}$ at $37^{\circ} \mathrm{C}$ in a $5-10 \% \mathrm{CO}_{2}$ incubator for the survival of bacteria under study. After incubation, as an indicator of bacterial growth, $50 \mu \mathrm{L}$ of $p$-iodonitrotetrazolium chloride (INTC) $(0.2 \mathrm{mg} / \mathrm{mL})$ was added to each well and then the plate was further incubated for $\sim 40$ min to $1 \mathrm{~h}$ under similar conditions [18]. The wells with pink colour indicated the growth of bacteria. Whereas, the yellow coloured wells or colourless wells indicated no bacteria growth (formation of formazan). The MIC was recorded as the lowest concentration that could not produce the visible bacteria growth. This cytotoxicity test was conducted using 3-(4,5-dimethylthiazol- 2-yl)-2,5-diphenyltetrazolium bromide (MTT) assay [19]. Liver cell line $(\mathrm{C} 3 \mathrm{~A})$ at a density of $5.0 \times 10^{4} \mathrm{cells} / \mathrm{mL}$ in minimum essential medium (MEM) supplemented with $10 \%$ FCS and $1 \%$ penicillin/streptomycin solution were seeded into each well $(200 \mu \mathrm{L})$ of a 96-well plate for the toxicity assays. Following overnight incubation at $37^{\circ} \mathrm{C}$ in a $5 \% \mathrm{CO}_{2}$ incubator, the media of cells were removed and replaced with $200 \mu \mathrm{L}$ of fresh media containing either extracts $(1 \mathrm{mg} / \mathrm{mL})$ or doxorubicin $(01 \mathrm{mg} / \mathrm{mL})$ in six serial dilutions. After $48 \mathrm{~h}$ incubation, the media were removed and fresh media containing $30 \mu \mathrm{L}$ of MTT $(5 \mathrm{mg} / \mathrm{mL}$ in PBS) were added into each well. After a further incubation period $(4 \mathrm{~h})$, the media were

\section{TABLE-1}

SOUTH AFRICAN MEDICINAL PLANTS INVOLVED IN THE CURRENT PROJECT AND THEIR MEDICINAL USES

\begin{tabular}{|c|c|c|c|c|c|c|}
\hline Scientific name & Common name & Family & $\begin{array}{l}\text { Plant part } \\
\text { used }\end{array}$ & Traditional used & Pharmaceutical usage & Ref. \\
\hline Lantana rugosa & Bird's brandy & Verbenaceae & Leaves & $\begin{array}{l}\text { Bronchitis, } \\
\text { inflammation of the } \\
\text { passages and colds }\end{array}$ & Anti-inflammatory & {$[11]$} \\
\hline Lippia wilmsii & & Verbenaceae & Leaves & Treatment of fits & Antibacterial & {$[12,13]$} \\
\hline Lippia javanica & $\begin{array}{l}\text { Lemon Bush or Fever tea } \\
\text { Musukudu (Batswana) } \\
\text { Umsuzwana (Zulu) }\end{array}$ & Verbenaceae & $\begin{array}{l}\text { Leaves, } \\
\text { Twigs \& } \\
\text { Roots }\end{array}$ & Coughs, Colds & $\begin{array}{l}\text { Decongestant, strong fever and } \\
\text { Bronchitis anti-septic effects } \\
\text { and anti-inflammatory activity }\end{array}$ & [14] \\
\hline $\begin{array}{l}\text { Hilliardiella } \\
\text { elaeagnoides }\end{array}$ & $\begin{array}{l}\text { Bicoloured- leaved } \\
\text { vernonia } \\
\text { Ihlambihloshane (Zulu) }\end{array}$ & Asteraceae & Leaves & $\begin{array}{l}\text { Abdominal pain } \\
\text { Indigestion, } \\
\text { Rheumatism, Dysentery }\end{array}$ & $\begin{array}{l}\text { Antibacterial, Antifungal, } \\
\text { Dose-dependent, Diabetes } \\
\text { Immunomodulation }\end{array}$ & [14] \\
\hline $\begin{array}{l}\text { Withania } \\
\text { somnifera }\end{array}$ & $\begin{array}{l}\text { Ashwagandha, or Winter } \\
\text { cherry Ubuvimbha (Zulu) } \\
\text { Bofepha (Sotho) }\end{array}$ & Solanaceae & $\begin{array}{l}\text { Roots and } \\
\text { leaves }\end{array}$ & $\begin{array}{l}\text { Neurological disorders } \\
\text { Geriatric debilities } \\
\text { Arthritis, Stress } \\
\text { behaviour related }\end{array}$ & $\begin{array}{l}\text { Antibiotic, Antioxidant, Anti- } \\
\text { inflammatory, Anti-tumor } \\
\text { activities }\end{array}$ & {$[14,15]$} \\
\hline
\end{tabular}


replaced with $50 \mu \mathrm{L}$ of undiluted DMSO to dissolve the MTT crystals at the bottom of the wells. Absorbance was measured at $570 \mathrm{~nm}$ after gentle shaking in a microplate reader. The $\mathrm{LC}_{50}$ values were calculated from a plot of log of concentration versus average absorbance of extract that resulted in a $50 \%$ reduction of absorbance in comparison to the untreated cells.

\section{RESULTS AND DISCUSSION}

The results of the screening test of plant extracts for antibacterial activity are presented in Table-2. Twenty-five extracts belonging to five plants species were investigated. This study found that selected bacteria strains were sensitive, to varying degrees, to the extracts of plants species. In each case, the inhibitory activity was expressed as an MIC value. Among the plants tested, Lippia javanica showed the best antibacterial activity. While poor inhibitory activity was detected for the microorganism E. coli, Gram-negative bacteria with all the plants species' extracts tested. The acetone extracts were very active against all types of tested bacteria, generally showing higher MIC values compared to other extracts. The extracts of Lippia javanica (acetone, ethyl acetate and methanol extracts) inhibited the highest in decreasing order the activity of $P$. aeruginosa, Gram-negative bacteria while all the extracts of Lantana rugosa with the exception of hexane extract as well as the methanol and acetone extracts of Withania somnifera inhibited the activity of $P$. aeruginosa to a lesser extent. In addition, Lippia javanica acetone extracts also inhibited the highest activity of $S$. aureus, Gram-positive bacteria.

Gibbons [20] demonstrated that natural products, such as plant extracts, are only considered as being of any real significance for medicinal drug development, if, in the presence of bacteria, they produce a MIC value below $1 \mathrm{mg} / \mathrm{mL}$. Based on their MIC values, all the extracts of Lippia javanica were very active against the bacteria $P$. aeruginosa with MIC values ranging from $0.04 \pm 0.04$ to $0.91 \pm 0.49 \mathrm{mg} / \mathrm{mL}$ with the acetone extract having the highest $(0.04 \pm 0.04) \mathrm{MIC}$ value. In addition, the methanol and acetone extracts of the same plant were very active against $S$. aureus with MIC values of $0.81 \pm 0.60$ and $0.28 \pm 0.35 \mathrm{mg} / \mathrm{mL}$, respectively. As expected, gentamycin used as control, proved to be the best overall antimicrobial substance used in this experiment for inhibiting bacterial growth, despite indications that the bacteria $S$. aureus may be becoming resistant to this medication.

Other studies had reported observing antibacterial activity occurring in some plants, but in most of such studies, only a single solvent was used. The present study, on the other hand, used five different solvents of varying polarity to compensate for the unknown characteristics and polarity of various compounds contained in these plants during the extraction process. Mujovo et al. [21] found the phenolic compound apigenin, a known antibacterial agent, in Lippia javanica, which might be responsible for the antibacterial activity against different types of

TABLE-2

MIC RESULTS OF LEAVES EXTRACTS OF FIVE SOUTH AFRICAN MEDICINAL PLANTS FOR SCREENED FOR THEIR ANTIBACTERIAL ACTIVITY EXPRESSED $(\mathrm{mg} / \mathrm{mL})$

\begin{tabular}{|c|c|c|c|c|c|}
\hline \multirow{2}{*}{ Plant } & \multirow{2}{*}{ Solvents used } & \multicolumn{4}{|c|}{ Bacteria tested $\left(\mathrm{MIC}^{*}(\mathrm{mg} / \mathrm{mL})\right.$} \\
\hline & & E. coli & E. faecalis & S. aureus & $P$. aeruginosa \\
\hline \multirow{6}{*}{ L. wilmsii } & Water & $5.34 \pm 5.18$ & $4.43 \pm 2.58$ & $3.65 \pm 1.95$ & $3.65 \pm 1.95$ \\
\hline & Methanol & $8.33 \pm 2.95$ & $6.25 \pm 0.00$ & $2.61 \pm 0.74$ & $5.21 \pm 1.47$ \\
\hline & Ethyl acetate & $6.25 \pm 0.00$ & $3.65 \pm 1.95$ & $11.46 \pm 9.66$ & $1.08 \pm 1.45$ \\
\hline & Acetone & $6.25 \pm 0.00$ & $1.82 \pm 0.98$ & $0.42 \pm 0.28$ & $4.19 \pm 5.88$ \\
\hline & Hexane & $9.38 \pm 11.40$ & $1.14 \pm 1.41$ & $2.41 \pm 2.79$ & $3.12 \pm 2.21$ \\
\hline & Gentamycin & $0.01 \pm 0.00$ & $0.07 \pm 0.08$ & $0.01 \pm 0.00$ & $0.01 \pm 0.00$ \\
\hline \multirow{6}{*}{ L. javanica } & Water & $1.30 \pm 0.37$ & $4.17 \pm 2.94$ & $4.29 \pm 2.76$ & $0.91 \pm 0.49$ \\
\hline & Methanol & $6.25 \pm 0.00$ & $2.09 \pm 1.47$ & $0.39 \pm 0.31$ & $0.15 \pm 0.17$ \\
\hline & Ethyl acetate & $6.25 \pm 0.00$ & $1.57 \pm 1.27$ & $0.81 \pm 0.60$ & $0.10 \pm 0.07$ \\
\hline & Acetone & $6.25 \pm 0.00$ & $1.57 \pm 1.27$ & $0.28 \pm 0.35$ & $0.04 \pm 0.04$ \\
\hline & Hexane & $8.33 \pm 2.95$ & $2.22 \pm 1.29$ & $1.14 \pm 1.41$ & $0.78 \pm 0.55$ \\
\hline & Gentamycin & $0.01 \pm 0.00$ & $0.01 \pm 0.01$ & $0.04 \pm 0.04$ & $0.01 \pm 0.00$ \\
\hline \multirow{6}{*}{ L. rugosa } & Water & $4.29 \pm 2.76$ & $3.13 \pm 0.00$ & $4.29 \pm 2.76$ & $0.42 \pm 0.28$ \\
\hline & Methanol & $5.21 \pm 1.47$ & $2.22 \pm 1.29$ & $1.57 \pm 1.27$ & $0.45 \pm 0.24$ \\
\hline & Ethyl acetate & $4.17 \pm 1.47$ & $2.12 \pm 1.43$ & $1.57 \pm 1.27$ & $0.29 \pm 0.14$ \\
\hline & Acetone & $4.17 \pm 1.47$ & $1.63 \pm 1.20$ & $0.39 \pm 0.31$ & $0.22 \pm 0.39$ \\
\hline & Hexane & $5.21 \pm 1.47$ & $2.15 \pm 1.39$ & $8.39 \pm 5.80$ & $1.17 \pm 0.55$ \\
\hline & Gentamycin & $0.01 \pm 0.00$ & $0.03 \pm 0.02$ & $1.06 \pm 1.46$ & $0.14 \pm 0.18$ \\
\hline \multirow{6}{*}{ H. elaeagnoides } & Water & $2.86 \pm 2.42$ & $0.65 \pm 0.18$ & $7.29 \pm 3.89$ & $2.47 \pm 2.68$ \\
\hline & Methanol & $4.17 \pm 1.47$ & $2.12 \pm 1.43$ & $2.15 \pm 1.39$ & $1.82 \pm 0.98$ \\
\hline & Ethyl acetate & $2.35 \pm 1.11$ & $1.10 \pm 0.65$ & $1.58 \pm 1.26$ & $2.86 \pm 2.42$ \\
\hline & Acetone & $5.21 \pm 1.47$ & $1.05 \pm 0.73$ & $2.10 \pm 1.45$ & $1.17 \pm 0.55$ \\
\hline & Hexane & $6.25 \pm 0.00$ & $7.29 \pm 3.89$ & $3.65 \pm 1.95$ & $6.25 \pm 0.00$ \\
\hline & Gentamycin & $0.01 \pm 0.00$ & $0.01 \pm 0.00$ & $2.09 \pm 2.94$ & $0.01 \pm 0.00$ \\
\hline \multirow{6}{*}{ W. somnifera } & Water & $6.25 \pm 0.00$ & $4.17 \pm 2.94$ & $3.39 \pm 2.24$ & $3.13 \pm 0.00$ \\
\hline & Methanol & $6.25 \pm 0.00$ & $2.10 \pm 1.45$ & $1.58 \pm 1.26$ & $0.45 \pm 0.24$ \\
\hline & Ethyl acetate & $4.17 \pm 1.47$ & $2.09 \pm 1.47$ & $3.16 \pm 2.51$ & $1.69 \pm 1.12$ \\
\hline & Acetone & $2.61 \pm 0.74$ & $0.39 \pm 0.31$ & $1.57 \pm 1.27$ & $0.29 \pm 0.14$ \\
\hline & Hexane & $3.13 \pm 0.00$ & $0.52 \pm 0.36$ & $2.10 \pm 1.45$ & $1.30 \pm 0.37$ \\
\hline & Gentamycin & $0.01 \pm 0.00$ & $0.01 \pm 0.00$ & $0.01 \pm 0.01$ & $0.01 \pm 0.00$ \\
\hline
\end{tabular}

*Minimum inhibitory concentration (value expressed as mean \pm standard deviation with $n=3$ ) 
microorganisms, such as $S$. aureus, E. faecalis, E. coli and $P$. aeruginosa. According to Shikanga et al. [22], methanol extracts of Lippia javanica produced high levels of antibacterial activity with MIC values of 0.13 to $0.42 \mathrm{mg} / \mathrm{mL}$ against the four pathogenic bacteria used in this study, followed by Lippia wilmsii with MIC values of 0.31 to $0.63 \mathrm{mg} / \mathrm{mL}$ against the same bacteria. Lekganyane et al. [23] also tested the acetone extract of Lippia javanica and found that the plant extract possessed antibacterial activity against the same bacteria with MIC values ranging from 0.32 to $0.64 \mathrm{mg} / \mathrm{mL}$.

According to Heyman et al. [24], an ethanolic extract of Withania somnifera produced antibacterial activity against both the methicillin-resistant and sensitive $S$. aureus with MIC values ranging from 0.500 to $1.561 \mathrm{mg} / \mathrm{mL}$. Most studies conducted on the antibacterial activity of Withania somnifera used the agar diffusion method. A study by Santhi and Swaminathan [25] found that the acetonic extract of Withania somnifera attained higher inhibition zones against $S$. aureus, E. coli, $P$. aeruginosa, K. pneumonia, $P$. mirabilis and $S$. paratyphi B than the ethanolic extract. Alam et al. [26] found that methanolic extracts of leaves, flowers and roots parts of Withania somnifera possessed antibacterial properties. The leaf parts of this plant in particular producing higher inhibition zones than the other parts, attaining inhibition zones ranging from $19.00 \pm 1.48$ to $32.00 \pm 0.75 \mathrm{~mm}$ against the bacteria $E$. coli, S. typhi, C. freundii, $P$. aeruginosa and $K$. pneumonia. The antibacterial activity of acetone extract of Lantana rugosa revealed that it was very active against $E$. faecalis with an MIC value of $0.78 \mathrm{mg} / \mathrm{mL}$ and against $S$. aureus with an MIC value of $0.39 \mathrm{mg} / \mathrm{mL}$ [27]. However, to our best of knowledge, the antibacterial activity of Hilliardiella elaeagnoides had not been reported before. Thus, present study is considered to be the first to publish antibacterial potential of this plant species.

For cytotoxicity activity, the results (Table-3) have shown that most of the plants extracts were toxic to the liver cells, except for aqueous and acetonic extracts of Lippia wilmsii with an $\mathrm{LC}_{50}$ value of $>1000 \mu \mathrm{g} / \mathrm{mL}$ and hexane extract of Lippia javanica with an $\mathrm{LC}_{50}$ value of $>1000 \mu \mathrm{g} / \mathrm{mL}$. Lower levels of toxicity occurred in a number of extracts, such as ethyl acetate extract of Lippia wilmsii, methanolic extract of Lippia javanica, hexane extract of Lantana rugosa, aqueous extract of Hilliardiella elaeagnoides and hexane extract of Withania somnifera with the $\mathrm{LC}_{50}$ values ranging from 66.07 to $359.74 \mu \mathrm{g} / \mathrm{mL}$. Some researchers $[15,28]$ reported on the cytotoxicity of some plants. Different methods were used in past studies, such as brine shrimp method, in vivo assays in animals and a single solvent. The current study, on the other hand, used a range of solvents extracts against the $\mathrm{C} 3 \mathrm{~A}$ liver cell lines.
Lantana rugosa subjected to the brine shrimp examination method, tested positive for cytotoxicity [27]. Ayuko et al. [28] tested for cytotoxicity in Lippia javanica using the brine shrimp method and found that the plant was relatively non-cytotoxic showing an $\mathrm{LC}_{50}$ value of $>500 \mu \mathrm{g} / \mathrm{mL}$. Further cytotoxicity tests by other researchers [29], involving liver cells (HEPG-2) carried out on petroleum ether, chloroform, methanol and ethyl acetate extracts of Withania somnifera showed that this plant species was indeed toxic. This was supported by the findings of the present study where the extracts of Withania somnifera showed cytotoxic activity ranging from $0.29 \pm 1.42$ to 91.79 $\pm 1.36 \mu \mathrm{g} / \mathrm{mL}$ against the $\mathrm{C} 3 \mathrm{~A}$ liver cells.

Until now, no comprehensive investigation had been conducted into the cytotoxicity of Lippia wilmsii and Hilliardiella elaeagnoides or at least no reported studies could be traced. Present study has determined the levels of cytotoxicity of a number of plant extracts in their respective solvents. The levels of cytotoxicity varied in strength and have been ranked as "very toxic", "less toxic" and "not toxic". The aqueous and acetone extracts of Lippia wilmsii was not toxic, but the methanolic and hexane extracts were very toxic; all the extracts of Hilliardiella elaeagnoides were very toxic with the acetone extract showing the most toxicity. The results of present investigation also highlighted the need to conduct toxicity tests/studies of plants before using them in medicinal applications. It has been proposed that the cytotoxic activities of these plants may be caused by certain phytochemicals, such as alkaloids, tannins, terpenoids and flavonoids, which are all known to be toxic [30].

\section{Conclusion}

This study has demonstrated that the tested medicinal plants indeed have antibacterial properties, which account for their longstanding, effective use in South Africa as traditional medicinal remedies for a number of bacterial infections and diseases. These remedies are usually prepared as herbal teas and tonics. It remains important, however, the cytotoxicity of these plants be properly understood and taken into careful consideration before using them in traditional medicinal applications. It should be noted that of all plant-and-solvent combinations tested, only the aqueous and acetonic extracts of Lippia wilmsii and the hexane extract of Lippia javanica were found to have no toxic effects at all on the liver cells and therefore, only ones to be considered completely safe.

\section{ACKNOWLEDGEMENTS}

The authors thank the National Research Fund (NRF) for funding the project and the Department of Biology at Sefako Makgatho Health Sciences University for the support.

TABLE-3

RESULTS OF CYTOTOXICITY TESTS OF EXTRACTS OF THE FIVE PLANTS AGAINST C3A LIVER CELLS

\begin{tabular}{lccccc}
\hline \multirow{2}{*}{ Plants } & \multicolumn{3}{c}{ Cytotoxicity $(\mu \mathrm{g} / \mathrm{mL})$} \\
\cline { 2 - 6 } \multicolumn{1}{c}{ Aqueous extract } & Methanol extract & Ethyl acetate extract & Acetone extract & Hexane extract \\
\hline L. wilmsii & $>1000$ & $0.10 \pm 0.18$ & $81.92 \pm 0.16$ & $>1000$ & $0.03 \pm 0.31$ \\
L. javanica & $1.74 \pm 0.44$ & $359.74 \pm 1.98$ & $31.10 \pm 0.18$ & $0.01 \pm 0.64$ & $>1000$ \\
L. rugosa & $41.81 \pm 1.04$ & $14.66 \pm 0.17$ & $6.39 \pm 0.18$ & $9.44 \pm 0.97$ & $181.94 \pm 1.00$ \\
H. elaeagnoides & $66.07 \pm 0.79$ & $5.64 \pm 0.06$ & $1.86 \pm 2.24$ & $0.55 \pm 1.63$ & $33.89 \pm 0.16$ \\
W. somnifera & $0.29 \pm 1.42$ & $0.71 \pm 0.19$ & $20.57 \pm 0.50$ & $0.65 \pm 0.25$ & $91.79 \pm 1.36$ \\
\hline
\end{tabular}

*Standard for cytotoxicity $\left(\mathrm{LC}_{50}\right.$ expressed as mean \pm standard deviation with $\mathrm{n}=3$ ).

This process was repeated (Positive control (doxorubicin) $\mathrm{LC}_{50}=0.004 \pm 0.06 \mu \mathrm{g}$. 


\section{CONFLICT OF INTEREST}

The authors declare that there is no conflict of interests regarding the publication of this article.

\section{REFERENCES}

1. D.M. Morens, G.K. Folkers and A.S. Fauci, Lancet Infect. Dis., 8, 710 (2008); https://doi.org/10.1016/S1473-3099(08)70256-1.

2. U.A. Khan, H. Rahman, Z. Niaz, M. Qasim, J. Khan, Tayyaba and B. Rehman, Eur. J. Microbiol. Immunol., 3, 272 (2013); https://doi.org/10.1556/EuJMI.3.2013.4.6.

3. L. Cole and P.R. Kramer, Human Physiology, Biochemistry and Basic Medicine, Elsevier Inc., London, San Diego, pp. 193-195 (2016).

4. M. Obeidat, M. Shatnawi, M. Al-Alawi, E. Al-Zu'bi, H. Al-Dmoor, M. Al-Qudah, J. El-Qudah and I. Otri, Res. J. Microbiol., 7, 59 (2012); https://doi.org/10.3923/jm.2012.59.67.

5. C.J. Botha and M.L. Penrith, J. Ethnopharmacol., 119, 549 (2008); https://doi.org/10.1016/j.jep.2008.07.022.

6. B.E. van Wyk, F.R. van Heerden and B. van Oudtshoorn, Poisonous plants of South Africa, Briza Publications: Pretoria, South Africa (2002).

7. J. Joubert, Clin. Toxicol., 28, 85 (1990); https://doi.org/10.3109/15563659008993478.

8. E. von Koenen, Medicinal, Poisonous and Edible Plants in Namibia, Klaus Hess Publishers: Windhoek, Namibia, edn 4 (2001).

9. E. Osuch, Thesis, Toxicological Aspects of Some Traditional Medicines used by Patients Admitted to Ga-Rankuwa Hospital, Medunsa, Pretoria, South Africa (1996).

10. W.J. du Plooy, M.R. Jobson, E. Osuch, L. Mathibe and P. Tsipa, S. Afr. J. Sci., 97, 70 (2001)

11. E. von Koenen, Medicinal, Poisonous, and Edible Plants in Namibia. Klaus Hess Publishers: Windhoek, Namibia, edn 4 (2001).

12. M. Sandasi, G.P.P. Kamatou, S. Combrinck and A.M. Viljoen, Biochem. Syst. Ecol., 51, 142 (2013); https://doi.org/10.1016/j.bse.2013.08.028.

13. https://www.zimbabweflora.co.zw/speciesdata/species-display.php? species_id=1082 50, retrieved 16 April 2019.
14. B.E. van Wyk, B. van Oudtshoorn and N. Gericke, Medicinal Plants of South Africa, Second Impression, Briza Publications: Pretoria, South Africa, edn 2 (2013).

15. D. Amenu, Am. J. Ethno., 1, 018 (2014).

16. L.J. McGaw, T. Rabe, S.G. Sparg, A.K. Jäger, J.N. Eloff and J. van Staden, J. Ethnopharmacol., 75, 45 (2001); https://doi.org/10.1016/S0378-8741(00)00405-0.

17. J.N. Eloff, Planta Med., 64, 711 (1998); https://doi.org/10.1055/s-2006-957563.

18. M.T. Olivier, F.M. Muganza, L.J. Shai, S.S. Gololo and L.D. Nemutavhanani, S. Afr. J. Bot., 108, 41 (2017); https://doi.org/10.1016/j.sajb.2016.09.014.

19. T. Mosmann, J. Immunol. Methods, 65, 55 (1983); https://doi.org/10.1016/0022-1759(83)90303-4.

20. S. Gibbons, Nat. Prod. Rep., 21, 263 (2004); https://doi.org/10.1039/b212695h.

21. S.F. Mujovo, A.A. Hussein, J.J.M. Meyer, B. Fourie, T. Muthivhi and N. Lall, Nat. Prod. Res., 22, 1047 (2008); https://doi.org/10.1080/14786410802250037.

22. E.A. Shikanga, S. Combrinck and T. Regnier, S. Afr. J. Bot., 76, 567 (2010); https://doi.org/10.1016/j.sajb.2010.04.010.

23. M.A. Lekganyane, T.M. Matsebatlela, R.L. Howard, L.J. Shai and P. Masoko, Afr. J. Biotechnol., 11, 13210 (2012).

24. H.M. Heyman, A.A. Hussein, J.J.M. Meyer and N. Lall, Pharm. Biol., 47, 67 (2009); https://doi.org/10.1080/13880200802434096.

25. M. Santhi and C. Swaminathan, Int. J. Curr. Res., 3, 10 (2011).

26. N. Alam, M. Hossain, M.A. Mottalib, S.A. Sulaiman, S.H. Gan and M.I. Khalil, BMC Complement. Altern. Med., 12, 1175 (2012); https://doi.org/10.1186/1472-6882-12-175.

27. L.J. McGaw, J.N. Eloff and J.J.M. Meyer, S. Afr. J. Bot., 71, 302 (2005); https://doi.org/10.1016/S0254-6299(15)30102-2.

28. T.A. Ayuko, R.N. Njau, W. Cornelius, N. Leah and I.O. Ndiege, Mem. Inst. Oswaldo Cruz, 104, 689 (2009); https://doi.org/10.1590/S0074-02762009000500004.

29. H. Samir, M.S. Abbas, A.S.H. Soliman and R.A. Lotfy, Res. J. Pharm. Biol. Chem. Sci., 9, 82 (2018).

30. N.J. Murugi, N.M. Piero, K.C. Mwiti, N.N.J. Joseph, N.E.N. Mwaniki, N.M. Wilson, M. David and G.P. Karuri, Asian Pharm. Clin. Res., 5, 69 (2012). 